\section{Computerized analysis of seedling performance in evaluating the phytotoxicity of chemical treatment of soybean seeds}

\author{
Gustavo Roberto Fonseca de Oliveira ${ }^{1 *}$ (D), Silvio Moure Cicero² (iD, Francisco \\ Guilhien Gomes-Junior ${ }^{2}$ (D), Thiago Barbosa Batista ${ }^{1}$ (D), Francisco Carlos \\ Krzyzanowski $^{3}$ (D) José de Barros França-Neto ${ }^{3}$
}

ABSTRACT: Chemical treatment of soybean seeds is very important to ensure successful crop establishment. However, problems such as phytotoxicity of product combinations that can reduce seed physiological performance require attention. The use of computational resources has shown potential in identifying phytotoxic effects and contributing to the steps of quality control of treated seeds. The aim of this study was to determine if computerized image analysis of seedlings enables the phytotoxicity of chemical treatment of soybean seeds to be assessed in an effective and simplified manner. Samples from two soybean seed lots were treated with fungicides, insecticides, micronutrients, and their combinations, as well as with polymer and drying powder (coatings). After chemical treatment, the seeds were evaluated for germination, first germination count, seedling emergence in sand, accelerated aging, and seedling performance with and without the correction of regions not automatically demarcated (Vigor-S). We found high correlation of the Vigor-S parameters with the traditional tests for detection of phytotoxic effects of chemical treatment, regardless of correction made in the system. Computerized image analysis of seedlings is an effective and highly sensitive resource for evaluating possible phytotoxicity effects due to chemical treatment of soybean seeds.

Index terms: computer vision, Glycine max L., image processing, seed treatment, Vigor-S system.

RESUMO: O tratamento químico de sementes de soja é muito importante para assegurar o sucesso no estabelecimento da lavoura. Contudo, deve-se ter atenção a problemas, como a fitotoxicidade de combinações de produtos, capazes de reduzir o desempenho fisiológico. $\mathrm{O}$ uso de recursos computacionais para identificar efeitos fitotóxicos têm potencial para integrar às etapas do controle de qualidade de sementes tratadas. $O$ objetivo foi verificar se a análise computadorizada de imagens de plântulas permite avaliar de forma eficiente e simplificada a fitotoxicidade do tratamento químico de sementes de soja. As sementes de dois lotes foram tratadas com fungicidas, inseticidas, micronutrientes e combinações entre eles, além de polímero e pó secante (recobrimentos). Após o tratamento químico, as sementes foram avaliadas quanto a germinação, primeira contagem de germinação, emergência de plântulas em areia, envelhecimento acelerado e o desempenho de plântulas com e sem a correção de regiões não demarcadas automaticamente (Vigor-S). Verificamos alta correlação dos parâmetros do Vigor-S com os testes tradicionais para detecção de efeitos fitotóxicos do tratamento químico, independente da correção feita no sistema. A análise computadorizada de imagens de plântulas é um recurso eficiente e de alta sensibilidade para avaliar a fitotoxicidade do tratamento químico de sementes de soja.

Termos para indexação: Glycine max L., tratamento de sementes, visão computacional, processamento de imagens, sistema Vigor-S.
Journal of Seed Science, v.43, e202143032, 2021

http://dx.doi.org/10.1590/ 2317-1545v43248996

\author{
*Corresponding author \\ E-mail: grfonseca.agro@gmail.com
}

Received: 02/22/2021. Accepted: 08/18/2021.

\footnotetext{
${ }^{1}$ Universidade Estadual Paulista (UNESP), Departamento de Produção Vegetal, 14884-900 Botucatu, SP, Brasil.
}

${ }^{2}$ Universidade de São Paulo (USP), Escola Superior de Agricultura Luiz de Queiroz, 13418-900 - Piracicaba, SP, Brasil.

${ }^{3}$ Embrapa Soja, Caixa Postal 231, 86001-970 - Londrina, PR, Brasil. 


\section{INTRODUCTION}

Chemical treatment of soybean seeds is used against biotic interferences after sowing (Ferreira et al., 2019). Especially soil pathogenic fungi and insect pests can have negative impacts in the initial stages of crop development (França-Neto et al., 2016) and on establishing plant stand. Mixtures of determined active ingredients are widely used in chemical treatment, but these mixtures may be phytotoxic to seeds and thus reduce their physiological potential ( Abati et al., 2018; Santos et al., 2018; Abati et al., 2020).

Many technologies are available for chemical treatment of soybean seeds, including mixtures of active ingredients (fungicides, insecticides, and nematicides), biological products (inoculants and biostimulants), micronutrients (cobalt, molybdenum, and zinc), and coating products (polymer and drying powder) (França-Neto et al., 2016). This range of products reinforces the need for testing their effectiveness in a rapid and precise manner, since certain combinations may compromise the physiological potential of soybean seeds (Brzezinski et al., 2017; Abati et al., 2020).

It should be emphasized that seeds with greater physiological potential have a greater ability to germinate and establish seedlings rapidly and uniformly (Finch-Savage and Bassel, 2016), factors reported as crucial for achieving high yields (Bagateli et al., 2019; Struker et al., 2019; Ebone et al., 2020). Thus, methods that deliver reliable information to the seed industry are important for identifying evidence of phytotoxicity brought about by chemical products in soybean seedlings.

Phytotoxicity in seeds is commonly manifested in root length (França-Neto et al., 2016; Carvalho et al., 2020). Computerized image analysis of seedlings can assist in detecting problems in this area. For example, Carvalho et al. (2020) highlighted the potential of analysis of root length of soybean seedlings in detecting the phytotoxicity of chemical treatment. The results of that study were obtained using image resources, which shows the potential of the technique for analyzing possible harmful effects of product combinations.

The Vigor-S system combines parameters that are strongly correlated with soybean seed vigor evaluated by traditional tests (Rodrigues et al., 2020). Research results from other species, such as common bean (Medeiros et al., 2019), maize (Castan et al., 2018), and melon (Leite et al., 2020), have also highlighted this potential of the system. The aim of this study was to determine if computerized image analysis of seedlings enables the phytotoxicity of chemical treatment of soybean seeds to be assessed in an effective and simplified manner.

\section{MATERIALS AND METHODS}

The study was conducted in the Seed Analysis and Image Analysis Laboratories of the Department of Plant Production of the "Escola Superior de Agricultura Luiz de Queiroz" (ESALQ), University of São Paulo (USP). Two seed lots of the soybean cultivar M6410 IPRO from the 2017/2018 crop season were used. The seed lots used had different vigor levels and low total incidence of pathogenic fungi $(<3 \%)$. The percentage of mechanical damage (sum of visible and non-visible damage) was evaluated by the sodium hypochlorite test, which indicated that $8 \%$ of the seeds of Lot 1 and $7 \%$ of the seeds of Lot 2 had cracks in the seed coat. These values are considered acceptable according to Krzyzanowski et al. (2004).

Seed chemical treatment: five $500 \mathrm{~g}$ samples of seed from each lot were chemically treated. One of the samples corresponded to the control (Treatment 1: seeds without chemical treatment), and different chemical treatments were used on the four other samples (Treatment 2: micronutrients; Treatment 3: fungicides + micronutrients; Treatment 4: insecticides + micronutrients; Treatment 5: fungicides + insecticides + micronutrients). The active ingredients and products used were added to the seeds with the aid of graduated syringes $(\mathrm{mm})$. The seeds were shaken in plastic bags for homogenization after each product was added. Polymer and drying powder (coatings) were applied at the end of the seed chemical treatment process. Seed moisture content at the time of chemical treatment was $10 \%$ (wet basis). A list of the treatments used with their respective products and doses is shown in Table 1. 
Table 1. Chemical treatment of 'M6410 IPRO' soybean seeds (Seed Treat.) with different active ingredients, formulated products, and respective doses applied according to the weight of the seed sample used.

\begin{tabular}{|c|c|c|c|c|c|c|c|c|}
\hline \multirow{2}{*}{ Seed Treat. * } & Sample & $\mathrm{F}^{1}$ & $1^{2}$ & $\mathrm{M}^{3}$ & $\mathrm{P}^{4}$ & Total & Total & $\mathrm{DP}^{5}$ \\
\hline & $\mathrm{g}^{* *}$ & \multicolumn{5}{|c|}{-------------- mL -------------- } & $\mathrm{mL} .100 \mathrm{~kg}^{-1}$ & g \\
\hline Treatment 1 & 500 & - & - & - & - & 0.0 & 0.0 & - \\
\hline Treatment 2 & 500 & - & - & 0.6 & 1.0 & 1.6 & 320 & 1.8 \\
\hline Treatment 3 & 500 & 1.0 & - & 0.6 & 1.0 & 2.6 & 520 & 1.8 \\
\hline Treatment 4 & 500 & - & 2.5 & 0.6 & 1.0 & 4.1 & 820 & 1.8 \\
\hline Treatment 5 & 500 & 1.0 & 2.5 & 0.6 & 1.0 & 5.1 & 1020 & 1.8 \\
\hline
\end{tabular}

*Seed treatment: Treatment 1 (control: seeds without chemical treatment); Treatment 2 (micronutrients); Treatment 3 (fungicides + micronutrients); Treatment 4 (insecticides + micronutrients); Treatment 5 (fungicides + insecticides + micronutrients);

$* *$ Weight $(\mathrm{g})$ of seeds under chemical treatment;

${ }^{1}$ Fungicides (formulation containing the mixture of carbendazim and thiram; $2 \mathrm{~mL} . \mathrm{kg}^{-1}$ );

${ }^{2}$ Insecticides (formulation containing the mixture of imidacloprid and thiodicarb; $5 \mathrm{~mL} . \mathrm{kg}^{-1}$ ).

${ }^{3}$ Micronutrients ( $\mathrm{CoMo}^{\circ}$ : formulation containing the mixture of cobalt and molybdenum; $1.2 \mathrm{~mL}^{-\mathrm{kg}^{-1}}$ );

${ }^{4}$ Polymer (Peridiam; $2{\left.\mathrm{~mL} . \mathrm{kg}^{-1}\right)}^{\circ}$;

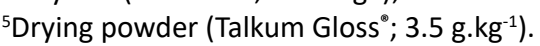

Seed physiological potential: seed physiological potential was assessed immediately after chemical treatment by the germination and vigor tests described below.

Germination test: four replications of 50 seeds from each treatment and from each seed lot were germinated in rolls of paper toweling moistened with water in the amount of 2.5 times the weight of the paper at $25{ }^{\circ} \mathrm{C}$. Normal seedlings were counted at five days (first germination count) and eight days (final germination) after setting up the test, according to the criteria established in the Rules for Seed Testing ("Regras para Análise de Sementes", Brasil, 2009).

Accelerated aging: this test was carried out according to the methodology proposed by Marcos-Filho (2020). After seed aging, two grams of seeds from each treatment and from each seed lot were used to determine moisture content, according to the criteria established in the Rules for Seed Testing (Brasil, 2009). After that, the germination test was set up along with the other seeds, as described above. Normal seedlings were counted five days after setting up the test. The moisture content of the seeds after performing the accelerated aging test varied within the range of tolerance of 3-4\% (Table 2), according to Marcos-Filho (2020), in both lots studied.

Seedling emergence in sand: four replications of 50 seeds from each treatment and from each seed lot were sown at a depth of $3 \mathrm{~cm}$ in plastic trays $(32 \mathrm{~cm} \times 28 \mathrm{~cm} \times 10 \mathrm{~cm})$ using medium texture sand as a substrate. The water volume used in irrigation was calculated to reach $60 \%$ of water-holding capacity of the substrate. After that, the boxes remained in a non-controlled environment (covered shed) until counting of emerged seedlings, performed after stabilization of the first pair of fully open leaves.

Computerized image analysis of seedlings (Vigor-S): four replications of 20 seeds from each treatment and from each seed lot were distributed on the upper third of paper toweling moistened with water in the amount of 2.5 times the weight of the paper. The rolls of paper towel were kept at $25^{\circ} \mathrm{C}$ for three days. After that period, digital images (at 300 dpi, by a HP Scanjet 200 scanner) were made of the seedlings, and automated evaluation of seedling performance (vigor index, growth index, uniformity index, hypocotyl length, root length, and seedling length) was carried out as established by Rodrigues et al. (2020) using the Vigor-S system, with the particular aspect of performing analysis with or without correction with the assistance of the mouse of the seedling parts not automatically demarcated by the system.

Statistical analysis: the data were analyzed separately for each seed lot in accordance with the treatments applied. A completely randomized experimental design was used consisting of five treatments with four replications $(n=20)$. The resulting data met the presupposition of normality of the residuals, analyzed by the Shapiro Wilk test. Thus, analysis of 
variance ( $F$ test; $p \leq 0.05)$ was performed, and the means were compared by the Tukey test $(p \leq 0.05)$. Pearson correlation analysis (correlation matrix) was also performed on the data, and the significance of the coefficients obtained was tested at $1 \%$ and $5 \%$ probability. The correlation coefficients were interpreted as established by Zou et al. (2003).

\section{RESULTS AND DISCUSSION}

Here we bring together new perspectives regarding the potential of computerized image analysis of seedlings for rapid and accurate detection of the effect of combinations of products used for chemical treatment of soybean seeds.

The treatments did not compromise the germination percentage of the seeds of Lot 1 and Lot 2 (Table 2). In Lot 1, in the combination of fungicides + insecticides + micronutrients (Treatment 5), there was reduction in seed vigor in relation to the control, evaluated by the first germination count and accelerated aging tests (Table 2). However, that treatment did not compromise seedling emergence in sand. In contrast, in Lot 2 , the combination of insecticides + micronutrients (Treatment 4) led to reduction in seedling emergence in sand as compared to the control. The seeds treated with the mixture of fungicides + insecticides + micronutrients (Treatment 5) had lower vigor in relation to Treatments 1 (control) and 3 (seeds treated with fungicides and micronutrients). No differences in vigor were detected among the five treatments in evaluation by the first germination count. The accelerated aging test indicated the greatest decline in vigor - in seeds treated with the mixture of fungicides + insecticides + micronutrients (Treatment 5). This indicates that soybean seeds treated with that mixture may have low performance after storage.

Table 2. Effects of chemical treatment in two soybean seed lots (Seed treat.): germination percentage (Germ), first germination count $(F C)$, seedling emergence in sand $(S E)$, accelerated aging $(A A)$, and moisture content after accelerated aging (MC-AA).

\begin{tabular}{|c|c|c|c|c|c|}
\hline \multirow{2}{*}{ Seed treat. ${ }^{1}$} & Germ (\%) & $\mathrm{FC}(\%)$ & SE (\%) & $A A(\%)$ & MC-AA (\%) \\
\hline & \multicolumn{5}{|c|}{ Lot 1} \\
\hline Treatment 1 & $97 a^{*}$ & $93 a$ & $92 \mathrm{a}$ & $85 a$ & 26.1 \\
\hline Treatment 2 & $91 \mathrm{a}$ & $85 a b$ & $91 \mathrm{a}$ & $78 \mathrm{a}$ & 25.6 \\
\hline Treatment 3 & $90 \mathrm{a}$ & $85 a b$ & $91 \mathrm{a}$ & $88 \mathrm{a}$ & 27.5 \\
\hline Treatment 4 & $91 \mathrm{a}$ & $86 a b$ & $92 \mathrm{a}$ & $81 \mathrm{a}$ & 27.0 \\
\hline Treatment 5 & $88 \mathrm{a}$ & $81 \mathrm{~b}$ & $87 a$ & $66 \mathrm{~b}$ & 25.3 \\
\hline LSD & 9.7 & 9.6 & 9.0 & 10.9 & - \\
\hline \multirow[t]{2}{*}{ C.V. (\%) } & 4.9 & 5.1 & 4.6 & 6.3 & - \\
\hline & \multicolumn{5}{|c|}{ Lot 2} \\
\hline Treatment 1 & $92 a^{*}$ & $88 \mathrm{a}$ & $92 \mathrm{a}$ & $84 \mathrm{a}$ & 26.1 \\
\hline Treatment 2 & $90 \mathrm{a}$ & $85 \mathrm{a}$ & $85 a b$ & $77 a b$ & 28.5 \\
\hline Treatment 3 & 93 a & $87 a$ & $86 a b$ & $80 \mathrm{a}$ & 27.6 \\
\hline Treatment 4 & $88 a$ & $81 \mathrm{a}$ & $78 \mathrm{~b}$ & $77 a b$ & 26.9 \\
\hline Treatment 5 & $90 \mathrm{a}$ & $78 \mathrm{a}$ & $84 a b$ & $69 \mathrm{~b}$ & 29.0 \\
\hline LSD & 9.3 & 11.4 & 12.1 & 10.9 & - \\
\hline C.V. (\%) & 4.7 & 6.3 & 6.5 & 6.5 & - \\
\hline
\end{tabular}

${ }^{1}$ Seed treatment: Treatment 1 (seeds without chemical treatment); Treatment 2 (micronutrients); Treatment 3 (fungicides + micronutrients); Treatment 4 (insecticides + micronutrients); Treatment 5 (fungicides + insecticides + micronutrients);

*Means followed by different lowercase letters in each column within each test differ from each other by the Tukey test at $5 \%$ probability;

C.V.: coefficient of variation;

LSD: least significant difference. 
Computerized analysis of the seedlings revealed that the seeds of Lot 1 treated with fungicides + insecticides + micronutrients (Treatment 5) gave rise to seedlings with lower vigor, growth, and uniformity indexes, and shorter hypocotyl, root, and seedling lengths (Table 3). In addition, phytotoxic effects caused by the mixture of fungicides + insecticides + micronutrients (Treatment 5) were identified, regardless of whether or not corrections were made in the seedling parts. In this case, the seedling images with and without corrections after processing indicated practically the same reduction in root length ( $44 \%$ and $45 \%$, respectively) (Table 3$)$.

The seeds of Lot 2 treated with insecticides + micronutrients (Treatment 4 ) and fungicides + insecticides + micronutrients (Treatment 5) also gave rise to seedlings with lower vigor and growth indexes and shorter root and seedling lengths (Table 4). Images of seedlings from Lot 2 with and without corrections provided similar results. This was also found in Lot 1 , indicating that this correction procedure can be dispensed.

The treatments containing insecticides (imidacloprid e thiodicarb), whether in association with micronutrients and fungicides or not, were more harmful to seedling performance. This response was also reported in previous studies on soybean seeds presented by Camilo et al. (2017) and Ferreira et al. (2016). Treatments 4 and 5 led to an expressive decline in root length, confirming their potential phytotoxicity, mainly expressed in the root system of soybean seedlings (Carvalho et al., 2020). The vigor and growth indexes, as well as the root length and whole seedling length, consistently indicated the lower performance of seeds coming from Treatments 4 and 5 . Nevertheless, the development uniformity index did not detect that response with the same consistency. This result can be fully

Table 3. Effect of chemical treatment of soybean seeds (Seed treat.): vigor index (Vigor), growth index (Growth), development uniformity index (Unif.), hypocotyl length (Hypo. L.), root length (Root L.), and seedling length (Seedling L.) obtained for Lot 1, with and without correction in the Vigor-S system.

\begin{tabular}{|c|c|c|c|c|c|c|}
\hline \multirow{3}{*}{$\begin{array}{l}\text { Seed treat. }{ }^{1} \\
\text { Lot } 1\end{array}$} & Vigor & Growth & Unif. & Hypo. L. & Root L. & Seedling L. \\
\hline & \multicolumn{3}{|c|}{---------- Index ---------- } & \multicolumn{3}{|c|}{ |-------------- cm --------------- } \\
\hline & \multicolumn{6}{|c|}{ Without correction } \\
\hline Treatment 1 & $737 a^{*}$ & 729 a & $753 a$ & $1.9 \mathrm{a}$ & $6.4 \mathrm{a}$ & $8.6 \mathrm{a}$ \\
\hline Treatment 2 & $673 a$ & 662 a & $697 a b$ & $2.2 \mathrm{a}$ & $5.9 \mathrm{a}$ & $8.2 \mathrm{a}$ \\
\hline Treatment 3 & $711 \mathrm{a}$ & $686 a$ & $768 \mathrm{a}$ & $1.9 a b$ & $6.2 \mathrm{a}$ & $8.1 \mathrm{a}$ \\
\hline Treatment 4 & $583 a b$ & 546 a & $667 a b$ & $1.8 a b$ & $4.9 \mathrm{a}$ & $6.7 \mathrm{a}$ \\
\hline Treatment 5 & $385 b$ & $316 \mathrm{~b}$ & $547 \mathrm{~b}$ & $1.3 \mathrm{~b}$ & $2.8 \mathrm{~b}$ & $4.1 \mathrm{~b}$ \\
\hline LSD & 206.8 & 219.9 & 202.4 & 0.61 & 2.0 & 2.5 \\
\hline \multirow[t]{2}{*}{ C.V. (\%) } & 15.3 & 17.1 & 13.5 & 15.4 & 17.4 & 15.8 \\
\hline & \multicolumn{6}{|c|}{ With correction } \\
\hline Treatment 1 & $672 a^{*}$ & $627 a$ & $776 a$ & $3.2 \mathrm{a}$ & $5.8 \mathrm{a}$ & $9.0 \mathrm{a}$ \\
\hline Treatment 2 & $626 a$ & 596 a & $697 a b$ & $3.1 \mathrm{a}$ & $5.5 \mathrm{a}$ & $8.6 \mathrm{a}$ \\
\hline Treatment 3 & $650 a$ & $594 \mathrm{a}$ & $780 a b$ & $2.9 \mathrm{a}$ & $5.5 \mathrm{a}$ & $8.5 \mathrm{a}$ \\
\hline Treatment 4 & $540 a b$ & 479 a & $684 a b$ & $2.7 a b$ & $4.4 \mathrm{a}$ & $7.1 \mathrm{a}$ \\
\hline Treatment 5 & $375 \mathrm{~b}$ & $286 \mathrm{~b}$ & $583 \mathrm{~b}$ & $1.9 \mathrm{~b}$ & $2.6 \mathrm{~b}$ & $4.5 \mathrm{~b}$ \\
\hline LSD & 175.4 & 179.8 & 194.6 & 0.83 & 1.73 & 2.5 \\
\hline C.V. (\%) & 14.0 & 16.0 & 12.7 & 13.7 & 16.6 & 14.8 \\
\hline
\end{tabular}

${ }^{1}$ Seed treatment: Treatment 1 (seeds without chemical treatment); Treatment 2 (micronutrients); Treatment 3 (fungicides + micronutrients); Treatment 4 (insecticides + micronutrients); Treatment 5 (fungicides + insecticides + micronutrients);

"Means followed by different lowercase letters in each column within each test differ from each other by the Tukey test at $5 \%$ probability; C.V.: coefficient of variation;

LSD: least significant difference. 
explained by the fact that both low vigor seedlings and those with higher vigor can have similar development uniformity indexes.

The treatments of seeds with micronutrients (Treatment 2) and with the mixture of fungicides and micronutrients (Treatment 3) did not lead to decline in the vigor of seeds coming from Lots 1 and 2 (Tables 3 and 4). The treatment of soybean seeds with micronutrients (cobalt and molybdenum) is reported to be phytotoxic when the dose applied exceeds $2 \mathrm{~mL} . \mathrm{kg}^{-1}$, mainly when mixed with fungicides (carbendazim and thiram) and polymer (Bays et al., 2007). In this study, doses below the tolerated limit were used (Table 1). In relation to the treatment with fungicides (carbendazim and thiram), positive effects have been reported on physiological performance (Pereira et al., 2011) and on soybean seed health quality (Ferreira et al., 2019), also corroborating the results of this study (Tables 2, 3, and 4).

It should be emphasized that the expectation is that chemical treatment should not cause phytotoxic effects in seeds. Yet, that did not occur in the present study for treated seeds, especially with the mixture of fungicides + insecticides + micronutrients (Treatment 5; Figure 1). This harmful effect likely occurred due to the presence of the insecticides because, as previously reported, the mixture of fungicides with micronutrients did not cause phytotoxicity in seedlings. These results reinforce the need for attention to the combination of products one intends to apply on soybean seeds, as reported by Abati et al. (2020) and Brzezinski et al. (2017) in other studies with the crop.

The strong correlation between the parameters obtained by the Vigor-S system with those in which no corrections were made $(w)$, such as seedling length (Seedling $L ; r=0.99 * *$ ), vigor index (Vigor; $r=0.99 * *$ ), growth index (Growth;

Table 4. Effect of chemical treatment of soybean seeds (Seed treat.): vigor index (Vigor), growth index (Growth), development uniformity index (Unif.), hypocotyl length (Hypo. L.), root length (Root L.), and seedling length (Seedling L.) obtained for Lot 2, with and without correction in the Vigor-S system.

\begin{tabular}{|c|c|c|c|c|c|c|}
\hline \multirow{3}{*}{$\begin{array}{l}\text { Seed treat. }{ }^{1} \\
\text { Lot } 2\end{array}$} & Vigor & Growth & Unif. & Hypo. L. & Root L. & Seedling L. \\
\hline & \multicolumn{3}{|c|}{---------- Index --------- } & \multicolumn{3}{|c|}{ 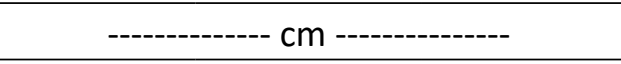 } \\
\hline & \multicolumn{6}{|c|}{ Without correction } \\
\hline Treatment 1 & 861 a* & 898 a & $775 \mathrm{a}$ & $2.4 \mathrm{a}$ & $8.2 \mathrm{a}$ & $10.6 \mathrm{a}$ \\
\hline Treatment 2 & 807 a & $834 \mathrm{a}$ & $747 a$ & $2.2 a b$ & $7.6 \mathrm{a}$ & $9.8 \mathrm{a}$ \\
\hline Treatment 3 & $730 a b$ & $747 a b$ & $691 \mathrm{a}$ & $2.1 \mathrm{ab}$ & $6.8 \mathrm{ab}$ & $8.9 a b$ \\
\hline Treatment 4 & $618 \mathrm{~b}$ & $598 b$ & $661 \mathrm{a}$ & $1.8 \mathrm{~b}$ & $5.4 b$ & $7.2 b$ \\
\hline Treatment 5 & $608 \mathrm{~b}$ & $581 \mathrm{~b}$ & $671 \mathrm{a}$ & $1.8 \mathrm{~b}$ & $5.3 \mathrm{~b}$ & $7.0 \mathrm{~b}$ \\
\hline LSD & 162.8 & 196.5 & 120.0 & 0.5 & 1.9 & 2.1 \\
\hline \multirow[t]{2}{*}{ C.V. (\%) } & 10.3 & 12.3 & 7.8 & 11.0 & 12.8 & 11.1 \\
\hline & \multicolumn{6}{|c|}{ With correction } \\
\hline Treatment 1 & $802 a^{*}$ & $810 \mathrm{a}$ & $786 a$ & $3.4 \mathrm{a}$ & $7.7 \mathrm{a}$ & $11.1 \mathrm{a}$ \\
\hline Treatment 2 & 748 a & $742 \mathrm{a}$ & 762 a & $3.3 \mathrm{a}$ & $7.0 \mathrm{a}$ & $10.4 \mathrm{a}$ \\
\hline Treatment 3 & $678 a b$ & $666 \mathrm{ab}$ & 699 a & $2.9 \mathrm{a}$ & $6.3 \mathrm{ab}$ & $9.3 \mathrm{ab}$ \\
\hline Treatment 4 & $571 b$ & $523 \mathrm{~b}$ & 676 a & $2.6 \mathrm{a}$ & $4.9 \mathrm{~b}$ & $7.6 \mathrm{~b}$ \\
\hline Treatment 5 & $570 \mathrm{~b}$ & $511 b$ & 708 a & $2.7 \mathrm{a}$ & $4.7 \mathrm{~b}$ & $7.5 \mathrm{~b}$ \\
\hline LSD & 145.2 & 172.7 & 114.3 & 1.0 & 1.7 & 2.3 \\
\hline C.V. (\%) & 9.9 & 12.1 & 7.2 & 15.2 & 12.7 & 11.6 \\
\hline
\end{tabular}

${ }^{1}$ Seed treatment: Treatment 1 (seeds without chemical treatment); Treatment 2 (micronutrients); Treatment 3 (fungicides + micronutrients); Treatment 4 (insecticides + micronutrients); Treatment 5 (fungicides + insecticides + micronutrients);

*Means followed by different lowercase letters in each column within each test differ from each other by the Tukey test at $5 \%$ probability; C.V.: coefficient of variation;

LSD: least significant difference. 


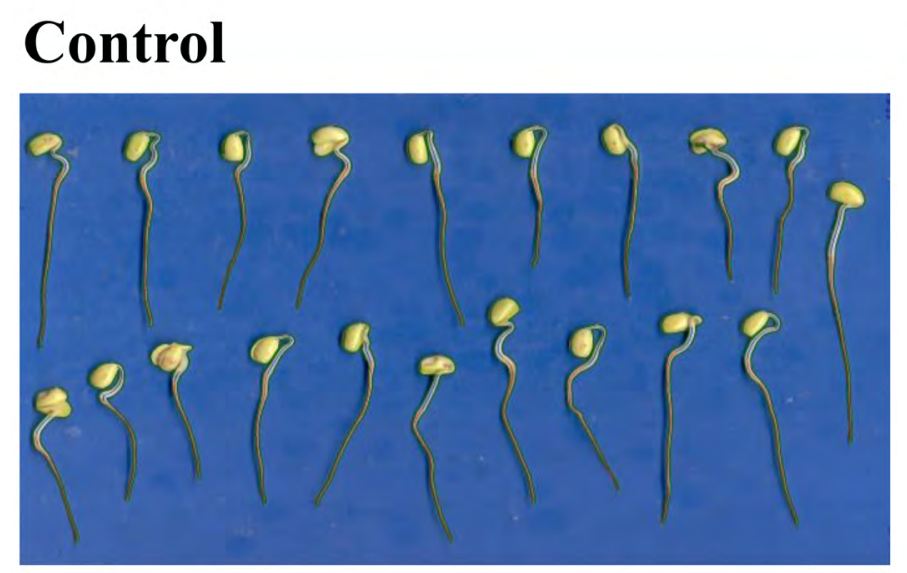

\section{Treatment 5}
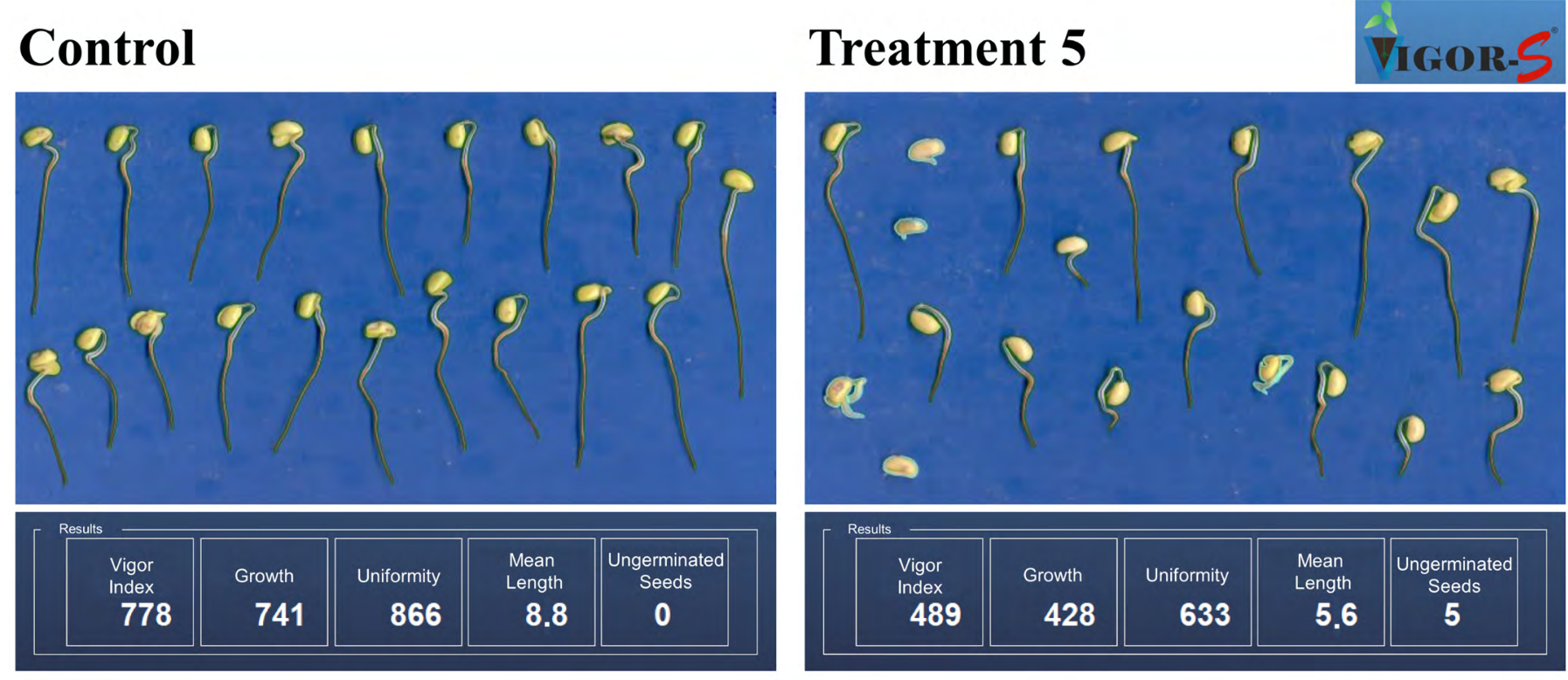

Figure 1. At the left, soybean seedlings originating from seeds without chemical treatment (Control). At the right, soybean seedlings originating from seeds treated with the mixture of fungicides, insecticides, and micronutrients (Treatment 5), exhibiting symptoms of phytotoxicity identified by the parameters of the Vigor-S system. Software with original interface translated into English.

$r=0.99^{* *}$ ), uniformity index (Unif; $r=0.98^{* *}$ ), hypocotyl length (Hypo L.; $r=0.93^{* *}$ ), and root length (Root L.; $r=$ $0.97^{* *}$ ) (Figure $2 \mathrm{~A}$ ), indicates that the use of images without correction does not compromise the accuracy of the results obtained in computerized analysis of seedlings. These results show that after image processing, the seedling parameters without correction were sufficient to identify differences in seed vigor brought about by the phytotoxicity of the chemical treatment (Tables 3 and 4). Among the traditional tests, only accelerated aging was correlated ( $r=\geq 0.5$ and $<0.8$ ) with the Vigor-S parameters (with and without correction), except for hypocotyl length ( $r=0.58 \mathrm{~ns}$ ) (Figure 2 ).

It is important to highlight that the parameters that constitute the Vigor-S correlated with the aging test, considered to be very effective for evaluating soybean seed vigor (Marcos-Filho, 2020). In practice, the fact that it is not necessary to work with corrections in Vigor-S (Figure 2B) to ensure reliable information (due to the small size of the regions not demarcated in the seedlings) speeds estimation of the vigor of the treated soybean seed lots. Compared to other vigor tests (first germination count, accelerated aging, and seedling emergence), computerized seedling analysis requires less time to carry out to obtain data, and it eliminates the subjectivity of interpretation inherent to the seed analyst.

The phytotoxicity observed (Tables 2, 3, and 4; Figure 1) had at least two main reasons: (i) the incompatibility of the mixture of active ingredients such as fungicides (carbendazim and thiram) and insecticides (imidacloprid and thiodicarb), which can compromise the vigor of seeds after treatment (Pereira et al., 2018) and (ii) the use of treatments with a high volume of the mixture applied, as observed in this study for Treatment $5\left(1020 \mathrm{~mL} . \mathrm{kg}^{-1}\right.$; Table 1), described as a determining factor for reduction in vigor (Santos et al., 2018; Abati et al., 2020). It has been reported that high volumes of the mixture applied together with the presence of mechanical damage lead to detachment of the seed coat, reducing the physiological performance of the seeds (França-Neto et al., 2016). Moreover, this effect may occur even before root emergence (Salanenka and Taylor, 2008; Taylor and Salanenka, 2012). For the seeds used in this study, the percentages of microcracks (Lot 1: $7 \%$ and Lot 2: $8 \%$ ) were within the acceptable limit of $10 \%$ (Krzyzanowski et al., 2004), which reinforces the first reason proposed as the main cause of the phytotoxicity observed in the seeds (i). 


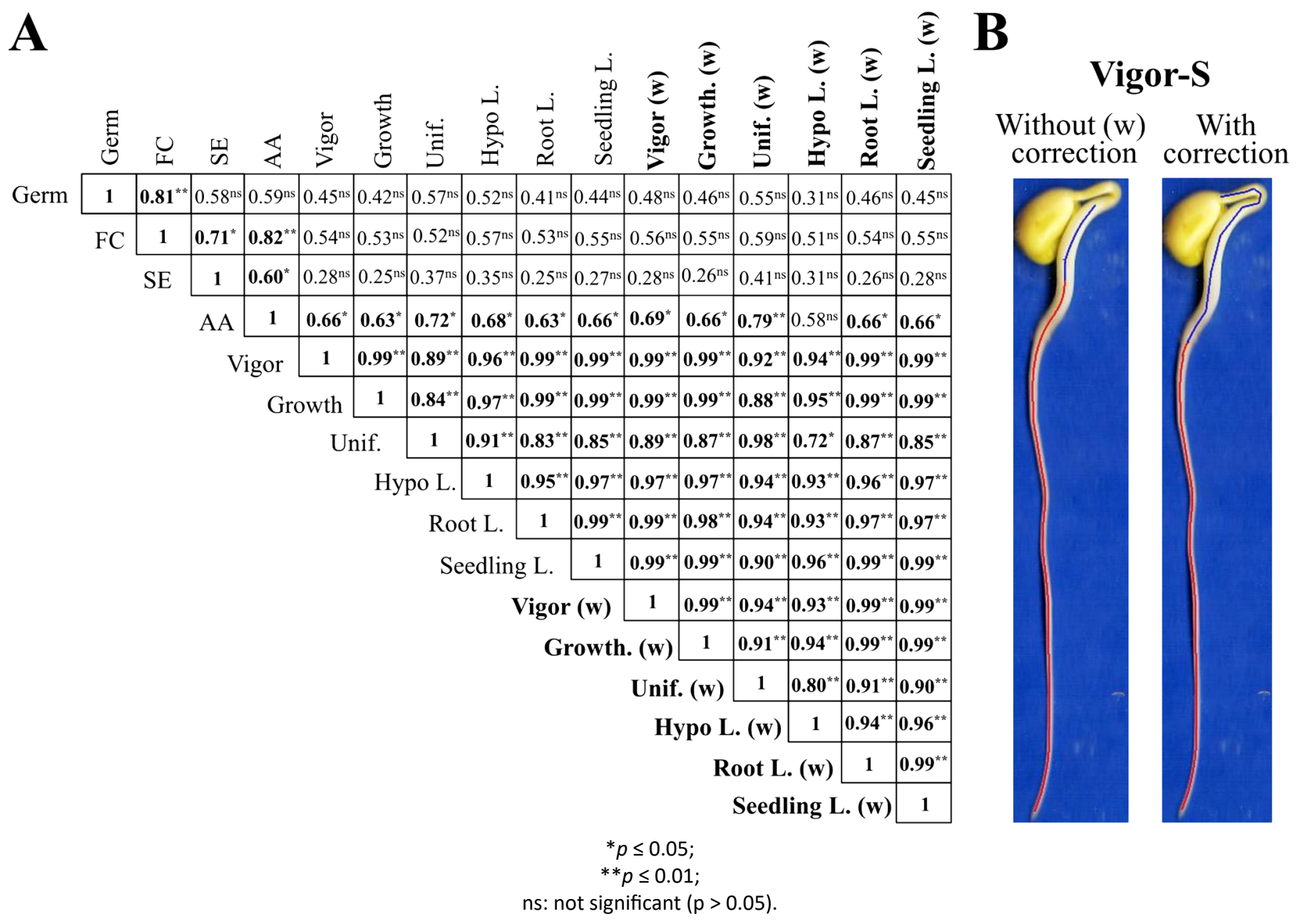

Figure 2. A: Correlation matrix (Pearson) obtained for the data observed in the germination test (Germ), first germination count test (FC), seedling emergence in sand (SE), accelerated aging (AA), and Vigor-S parameters, with and without $(w)$ the correction procedure, including vigor index (Vigor), growth index (Growth), growth uniformity index (Unif.), hypocotyl length (Hypo L.), root length (Root L.), and seedling length (Seedling L.). B: Images of soybean seedlings without the correction and after correction with assistance of the mouse of the seedling parts not automatically demarcated by the system.

Finally, the cause of phytotoxicity and the possible use of chemical treatment with diverse products lead to the need for studies that measure the impact of these products on seed physiological potential in a simplified manner. That way, adjustments can be made in the chemical treatment desired. These facts reinforce the importance of the present study since the parameters of computerized image analysis of seedlings were found to be a method that is rapid (three days), simple (as the parameters obtained do not need to be corrected), and effective for detecting the phytotoxicity of the chemical treatment. Therefore, the use of computational resources focusing on seedling performance constitutes a promising evaluation for inclusion in the steps of quality control of treated soybean seeds. It may also contribute to the seed industry in guiding the choice of chemical treatment technologies that are effective and high performing.

\section{CONCLUSIONS}

Computerized image analysis of seedlings, with use of the Vigor-S system, is an effective and highly sensitive resource for evaluating possible phytotoxicity effects due the chemical treatment of soybean seeds. 


\section{ACKNOWLEDGMENTS}

The authors thank the "Coordenação de Aperfeiçoamento de Pessoal de Nível Superior" (CAPES) for the scholarship granted to the first author. Thanks also to the professionals Helena Chamma (USP/ESALQ), Dr. Fernando A. Henning, Vilma Cardoso L. Stroka, Elpidio Alves, Antônio R. Melchiades, Waldemar de Oliveira Neto, and Adriana de Marques Freitas ("Núcleo Tecnológico de Sementes e Grãos", Embrapa Soybean) for valuable technical support in carrying out the study.

\section{REFERENCES}

ABATI, J.; BRZEZINSKI, C.R.; BERTUZZI, E.C.; HENNING, F.A.; ZUCARELI, C. Physiological response of soybean seeds to spray volumes of industrial chemical treatment and storage in different environments. Journal of Seed Science, v.42, p.1-12, 2020. http://dx.doi. org/10.1590/2317-1545v42221062

ABATI, J.; BRZEZINSKI, C.R.; ZUCARELI, C.; COSTA, D.S.; HENNING, A.A.; HENNING, F.A. Physiological potential of soybean seeds treated in the industry with and without the application of dry powder. Journal of Seed Science, v.40, n.2, p.179-184, 2018. https:// doi.org/10.1590/2317-1545v40n2190927

BAGATELI, J.R.; DÖRR, C.S.; SCHUCH, L.O.B.; MENEGHELLO, G.E. Productive performance of soybean plants originated from seed lots with increasing vigor levels. Journal of Seed Science, v.41, n.2, p.151-159, 2019. https://doi.org/10.1590/2317-1545v41n2199320

BAYS, R.; BAUDET, L.; HENNING, A.A.; LUCCA-FILHO, O. Recobrimento de sementes de soja com micronutrientes, fungicida e polímero. Revista Brasileira de Sementes, v.29, n.2, p.60-67, 2007. https://doi.org/10.1590/S0101-31222007000200009

BRASIL. Ministério da Agricultura, Pecuária e Abastecimento. Regras para análise de sementes. Ministério da Agricultura, Pecuária e Abastecimento. Secretaria de Defesa Agropecuária. Brasília: MAPA/ACS, 2009. 399p. https://www.gov.br/agricultura/pt-br/ assuntos/insumos-agropecuarios/arquivos-publicacoes-insumos/2946_regras_analise_sementes.pdf

BRZEZINSKI, C.R.; ABATI, J.; HENNING, F.A.; HENNING, A.A.; FRANÇA-NETO, J.B.; KRZYZANOWSKI, F.C.; ZUCARELI, C. Spray volumes in the industrial treatment on the physiological quality of soybean seeds with different levels of vigor. Journal of Seed Science, v.39, n.2, p.174-181, 2017. https://doi.org/10.1590/2317-1545v39n2175179

CAMILO, G.L.; CASTELLANOS, C.I.S.; SUÑÉ, A.S.; ALMEIDA, A.S.; SOARES, V.N.; TUNES, L.V.M. Qualidade fisiológica de sementes de soja durante o armazenamento após revestimento com agroquímicos. Revista de Ciências Agrárias, v.40, n.2, p.436-446, 2017. https://doi.org/10.19084/rca16145

CARVALHO, E.R.; ROCHA, D.K.; ANDRADE, D.B.; PIRES, R.M.O.; PENIDO, A.C.; REIS, L.V. Phytotoxicity in soybean seeds treated with phytosanitary products at different application times. Journal of Seed Science, v.42, p.1-12, 2020. https://doi.org/10.1590/23171545v42237847

CASTAN, D.O.C.; GOMES-JUNIOR, F.G.; MARCOS-FILHO, J. Vigor-S, a new system for evaluating the physiological potential of maize seeds. Scientia Agricola, v.75, n.2, p.167-172, 2018. https://doi.org/10.1590/1678-992x-2016-0401

EBONE, L.A.; CAVERZAN, A.; TAGLIARI, A.; CHIOMENTO, J.L.T.; SILVEIRA, D.C.; CHAVARRIA, G. Soybean seed vigor: uniformity and growth as key factors to improve yield. Agronomy, v.10, n.545, 2020. https://www.mdpi.com/2073-4395/10/4/545

FERREIRA, T.F.; CARVALHO, M.V.; FERREIRA, V.F.; MAVAIEIE, D.P.R.; GUIMARÃES, G.C.; OLIVEIRA, J.A. Sanitary quality of soybean seeds treated with fungicides and insecticides before and after storage. Journal of Seed Science, v.41, n.3, p.293-300, 2019. https:// doi.org/10.1590/2317-1545v41n3210498

FERREIRA, T.F.; OLIVEIRA, J.A.; CARVALHO, R.A.; RESENDE, L.S.; LOPES, C.G.M.; FERREIRA, V.F. Quality of soybean seeds treated with fungicides and insecticides before and after storage. Journal of Seed Science, v.38, n.4, p.278-286, 2016. https://doi. org/10.1590/2317-1545v38n4161760

FINCH-SAVAGE, W.E.; BASSEL, G.W. Seed vigour and crop establishment: extending performance beyond adaptation. Journal of Experimental Botany, v.67, n.3, p.567-591, 2016. https://doi.org/10.1093/jxb/erv490

FRANÇA-NETO, J.B.; KRZYZANOWSKI, F.C.; HENNING, A.A.; PÁDUA, G.P.; LORINI, I.; HENNING, F.A. Tecnologia da produção de semente de soja de alta qualidade. Embrapa Soja - Documentos, p.75, 2016. http://ainfo.cnptia.embrapa.br 
KRZYZANOWSKI, F.C.; FRANÇA-NETO, J.B.; COSTA, N.P. Teste do hipoclorito de sódio para semente de soja. Circular Técnica, n.37, p.1-4, 2004. https://www.infoteca.cnptia.embrapa.br

LEITE, M.S.; TORRES, S.B.; GOMES-JUNIOR, F.G.; REGO, C.H.Q.; PAIVA, E.P.; LEITE, T.S. Viability of seedling image analysis (Vigor-S) to determine the physiological potential of melon seeds. Journal of Seed Science, v.42, p.1-11, 2020. https://doi.org/10.1590/2317$1545 \mathrm{v} 42237826$

MARCOS-FILHO, J. Teste de envelhecimento acelerado. In: KRZYZANOWSKI, F.C.; VIEIRA, R.D.; FRANÇA-NETO, J.B.; MARCOS-FILHO, J. (Eds.) Vigor de sementes: conceitos e testes. $2^{\circ}$ Ed. Londrina: ABRATES, 2021. 601p.

MEDEIROS, A.D.; SILVA, L.J.; CAPOBIANGO, N.P.; FIALHO, C.A.; DIAS, D.C.F.S. Assessing the physiological quality of common bean seeds using the Vigor-S $S^{\circledR}$ system and its relation to the accelerated aging test. Journal of Seed Science, v.41, n.2, p.187-195, 2019. https://doi.org/10.1590/2317-1545v41n2211401

PEREIRA, C.E.; OLIVEIRA, J.A.; GUIMARÃES, R.M.; VIEIRA, A.R.; EVANGELISTA, J.R.E.; OLIVEIRA, G.E. Tratamento fungicida e peliculização de sementes de soja submetidas ao armazenamento. Ciência e Agrotecnologia, v.35, n.1, p.158-164, 2011. https:// doi.org/10.1590/S1413-70542011000100020

PEREIRA, L.C.; GARCIA, M.M.; BRACCINI, A.L.; FERRI, G.C.; SUZUKAWA, A.K.; MARTELI, D.C.V.; MATERA, T.C.; PEREIRA, R.C.; CORREIA, L.V. Physiological potential of soybean seeds over storage after industrial treatment. Journal of Seed Science, v.40, n.3, p.272-280, 2018. https://doi.org/10.1590/2317-1545v40n3185104

RODRIGUES, M.; GOMES-JUNIOR, F.G.; MARCOS-FILHO, J. Vigor-S: system for automated analysis of soybean seed vigor. Journal of Seed Science, v.42, e202042039, 2020. https://doi.org/http://dx.doi.org/10.1590/2317-1545v42237490

SALANENKA, Y.A.; TAYLOR, A.G. Seed coat permeability and uptake of applied systemic compounds. Acta Horticulturae, p.151-154, 2008. https://doi.org/10.17660/ActaHortic.2008.782.16

SANTOS, S.F.; CARVALHO, E.R.; ROCHA, D.K.; NASCIMENTO, R.M. Composition and volumes of slurry in soybean seeds treatment in the industry and physiological quality during storage. Journal of Seed Science, v.40, n.1, p.67-74, 2018. https://doi.org/10.1590/23171545v40n1185370

STRUKER, S.; CARVALHO, I.R.; SZARESKI, V.J.; BARBOSA, M.H.; SOUZA, V.Q.; CONTE, G.G.; MARTINS, A.B.N.; CAVALCANTE, J.A.; KOCH, F.; SCHUCH, L.O.B.; AUMONDE, T.Z.; VILLELA, F.A.; PEDÓ, T. Influence of seeds vigor in the attributes of soybean yield. Revista de Ciências Agrárias, v.42, n.3, p.111-120, 2019. https://doi.org/10.19084/rca.16389

TAYLOR, A.G.; SALANENKA, Y.A. Seed treatments: phytotoxicity amelioration and tracer uptake. Seed Science Research, v.22, p.8690, 2012. https://doi.org/10.1017/S0960258511000389

ZOU, K.H.; TUNCALI, K.; SILVERMAN, S.G. Correlation and simple linear regression. Radiology, v.227, n.3, p.617-628, 2003. https:// pubs.rsna.org/doi/abs/10.1148/radiol.2273011499?journalCode=radiology use, distribution, and reproduction in any medium, provided the original work is properly cited. 